\title{
Influence of Deep Cryogenic Processing on Carbide Grain Size in Sintered Car- bide WC-Co
}

\author{
Vojtěch Průcha ${ }^{1}$, Zdeněk Jansa ${ }^{2}$, Vilém Veselý1 \\ ${ }^{1}$ Department of Material Science and Technology, University of West Bohemia in Pilsen, Univerzitní 8, 30100 , \\ Pilsen, Czech Republic, E-mail: vprucha@kmm.zcu.cz, vesely.vilem@gmail.com \\ ${ }^{2}$ New Technologies - Research Center - University of West Bohemia in Pilsen, Teslova 1198/9, 30100 Pilsen 3, \\ Czech Republic, E-mail: zjansa@ntc.zcu.cz
}

The paper deals with the change in carbide grain size of sintered WC-Co carbide after cryogenic processing. Because this structural parameter has a significant effect on mechanical properties. Some sources indicate that due to cryogenic processing takes place to reduce the size of carbide grains and other sources indicate that takes place to increase the size of carbide grains. Measurement of the grain size can be performed using several methods. In this paper, a comparative method according to the ASTM B 390 standard was used. Further, the linear intersection method according to the ČSN ISO 4499-2 standard was used. The last one for measuring the grain size the image analysis software NIS - Elements AR v. 4.40 was used. Also, the size of the WC crystallites by XRD was measured. Crystallites are coherent diffraction domains in X-ray diffraction. The results show that due to cryogenic processing, the carbide grain increases but the size of the WC crystallites was decreasing.

Keywords: Grain Size, Crystallites, WC, Image Analysis, Deep Cryogennic Treatment

\section{Introduction}

Cemented carbides belong to the most widespread powder metallurgy products worldwide. The reason for this is their outstanding combination of hardness and toughness when compared to other cutting materials, such as diamond or high speed steels[1]. Appropriate combinations of hard phases (important is the size of grain also), metallic binder and processing parameters can lead to a wide range of microstructures with a variety of mechanical and electrical properties.

The first patents related to cemented carbides were granted in 1923 to the German company "Osram Studiengesellschaft". They concerned a method developed by K. Schröter to produce hard materials by pressing and sintering. In this process, tungsten monocarbide WC and metals like Fe, Ni and Co were liquid-phase sintered to produce a solid dense body. In 1927, the German company Friedrich Krupp marketed the first cemented carbide composed of tungsten carbide and cobalt (WC-Co) worldwide. It was given the name WIDIA (an acronym for the German words WIe DIAmant=like diamond). Cemented carbides were primarily used as materials for wire drawing dies and wear resistant parts. Early on, it was discovered that adding other carbides (such as $\mathrm{TiC}, \mathrm{TaC}$, $\mathrm{NbC}$ ) can improve the properties of the basic WC-Co composition when used in certain machining operations $[1,2,3]$.

The use of coatings to improve the performance of cutting tools, including those made of cemented carbides, dates back to the 1980s. Using coating processes like chemical vapor deposition (CVD) or physical vapor deposition (PVD), hard coatings such as TiC, TiN, $\operatorname{Ti}(\mathrm{C}, \mathrm{N})$ were deposited on the surface of cemented carbide substrates. Today, a majority of cutting tools are provided with rather costly coatings to reduce wear. One frequent and major limitation, however, is the complex shape of the tool. In recent years, in an effort to reduce costs, cutting tools are often just heat treated using various techniques instead of being coated.

Cryogenic treatment is considered to be the leading heat treatment process. There have been numerous studies on cryogenic treatment of cutting materials, many of them suggesting that it improves mechanical properties of the part. One of the causes is thought to be the change in the size of carbide grains. Some reports maintain that cryogenic processing reduces the size of carbide grains $[4,5]$, whereas others claim the opposite $[6,7]$.

The crystal structure of $\alpha$ phase (WC) is simple hexagonal with one tungsten and carbon atom per unit cell and an a/c ratio very close to unity (Fig. 1a). However, the stable shape of $\alpha$-phase crystals is a triangular prism as shown in Fig. 1b $[8,9,10]$.

In untreated WC-Co material, the stable shape is not fully developed because of impingement on other particles. Moreover, some large particles of close to the rectangular shape were found in the structure. It is thought that $\alpha$-phase particles of tungsten carbide are refined into their most stable form via spheroidization 
in cryogenically treated WC-Co material. The cryogenic temperature is believed to be a catalyst for preferential growth of three of the six prismatic tungsten carbide $\{10 \overline{1} 0\}$ planes (Fig. 1b) - which might have resulted in stable $\alpha$-phase particles shaped as triangular prisms. This partly explains why cryogenic processing increases tool life.

Larger carbide grain size in cryogenically-treated cemented carbide means larger thermal conductivity and in turn higher heat dissipation capacity of a cutting tool. This helps reduce the tool tip temperature and ultimately increases the tool life [11].

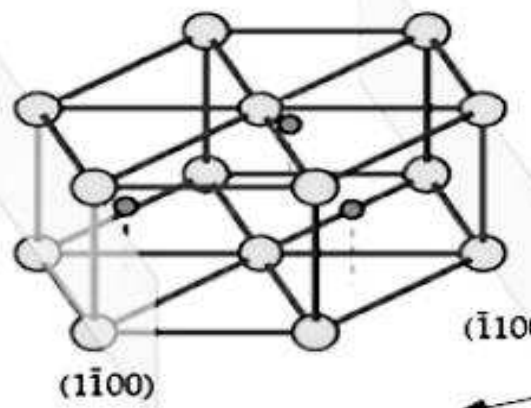

[1100]
$\mathrm{W}$
$\circ \mathrm{C}$

\section{2}

[0001]

Fig. 1 a The Hexagonal a-phase (WC) Cell and $\boldsymbol{b}$ Tungsten Carbide Grain Shape Resulting from Preferential Growth along Prismatic Planes [8]

\section{Experimental Parameters}

\subsection{Materials and Heat Treatment}

Two different grades of cemented carbides were studied. Which had coarse-grained with WC grains larger than $6 \mu \mathrm{m}$ and binder contents of 10 and $15 \mathrm{wt}$. $\%$. They were supplied by Ceratizit s.r.o. Table 1 gives some of their properties as declared by the manufacturer [12].

Tab. 1 Designations and selected properties of cemented carbides used in the experiments 127

\begin{tabular}{|c|c|c|c|c|}
\hline $\begin{array}{c}\text { Marking according } \\
\text { to the manufactu- } \\
\text { rer }\end{array}$ & $\begin{array}{c}\text { Co content } \\
{[\text { wt. } \%]}\end{array}$ & $\begin{array}{c}\text { WC grain size } \\
{[\mu \mathrm{m}]}\end{array}$ & HV30 & $\begin{array}{c}\text { Fracture toughness } \\
{\left[\mathrm{MPa} \cdot \mathrm{m}^{1 / 2}\right]}\end{array}$ \\
\hline CTE 30 & 15 & $>6 \mu \mathrm{m}$ & 960 & 22.0 \\
\hline CTE 20 & 10 & $>6 \mu \mathrm{m}$ & 1120 & 18.0 \\
\hline
\end{tabular}

Testing specimens were $50 \mathrm{~mm}$ in diameter and 7 $\mathrm{mm}$ in height. Their surface was ground and polished in Struers Tegramin 20 metallographic grinder prior to cryogenic treatment. The procedure used for surface preparation was standart procedure by Metalogram area $(\mathrm{F})[13]$.

Deep Cryogenic Treatment (DCT) was carried out in a cryogenic chamber at the company European Cryogenic Institute, s.r.o. Specimens were placed in the chamber and cooled by slow injection of liquid nitrogen. The process of cooling to the desired temperature of $-186^{\circ} \mathrm{C}$ took 8 hours. It was followed by a 16 -hour hold and slow reheating to room temperature over 6 hours.

\subsection{Characterization Methods}

Microstructures of the samples were revealed by chemical etching with Murakami's reagent. The procedure was according to ASTM B 657-92 standard (etching technique 3 - Identification of $\alpha$ phase) [14].
Observation and documentation of microstructure were performed using PHILIPS XL30 ESEM scanning electron microscope.

$\mathrm{X}$-ray diffraction analysis was performed using $\mathrm{Pa}$ nalytical X'Pert PRO automatic powder diffractometer with $\vartheta-\vartheta$ goniometer (symmetric geometry). The wavelength of the radiation emitted by its copper Xray tube was $\lambda_{\mathrm{K} \alpha 1}=0.15405980 \mathrm{~nm}$. Diffraction patterns from all specimens were collected within the range $30-125^{\circ} 2 \vartheta$. Reference diffraction patterns for all phases were obtained from the PDF2 database. The diffraction analysis procedure was the same for all the specimens. The irradiated region under analysis was $20 \times 20 \mathrm{~mm}$.

\section{Results and Discussion}

First of all the grain size using a comparison method according to ASTM B390 [15] was measured. The five images were made for comparison. The comparison is performed on images at a magnification of 
1,500x by comparison with a sample diagram, see Fig. 2. This method is very fast, but not very accurate The estimated grain size of the CTE20 (10\% Co) sample before DCT was $8 \mu \mathrm{m}$, after DCT was $10 \mu \mathrm{m}$. The estimated grain size of the CTE30 $(15 \% \mathrm{Co})$ sample before DCT was $8 \mu \mathrm{m}$, after DCT was $10 \mu \mathrm{m}$. An example micrographs of specimens before and after cryogenic treatment are shown in Fig. 3 and 4.

The second method used to measure grain size was the linear intersection method according to the CSN ISO 4499-2 standard. Again, five images were used. The backscattered electron mode was used to increase the chemical contrast of the phases for this method. Almost 300 grains were measured on the CTE20 (10\% Co) sample before DCT. The average grain size was $4.26 \pm 0.96 \mu \mathrm{m}$. More than 300 grains were measured on the CTE20 $(10 \%$ Co) sample after DCT. The average grain size was $4.43 \pm 0.67 \mu \mathrm{m}$. More than 200 grains were measured on the CTE30 (15\% Co) sample before DCT. The average grain size was $4.39 \pm 0.54$ $\mu \mathrm{m}$. More than 300 grains were measured on the CTE30 (15\% Co) sample after DCT. The average grain size was $4.73 \pm 0.57 \mu \mathrm{m}$. The measured grain sizes are in the graph for comparison, see Fig. 5. This method is very time-consuming, but more accurate. The results shows that the carbide grain size increased after cryogenic treatment.

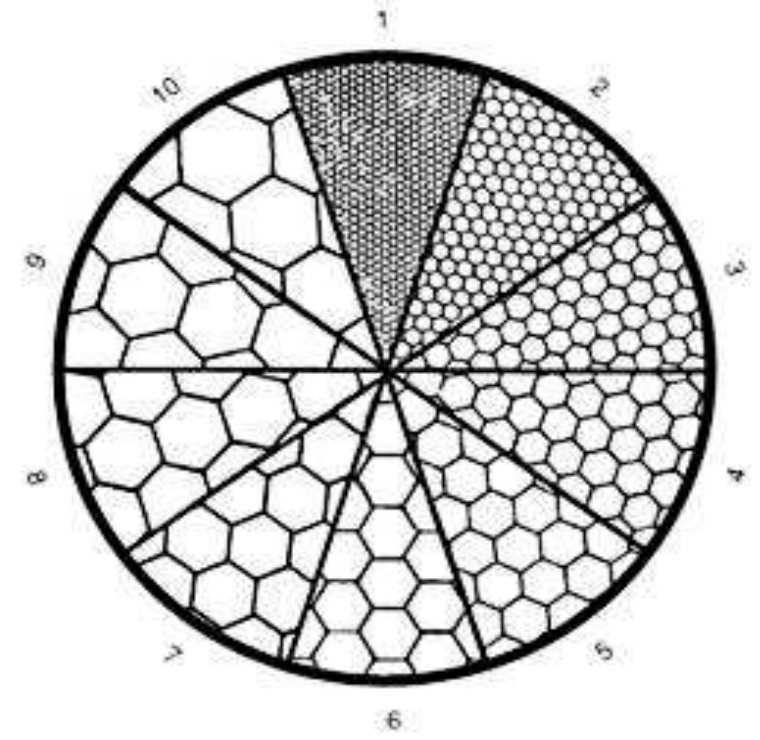

Fig. 2 Relationship of Grain Sizes at Magnification of 1500 Diameters [15]

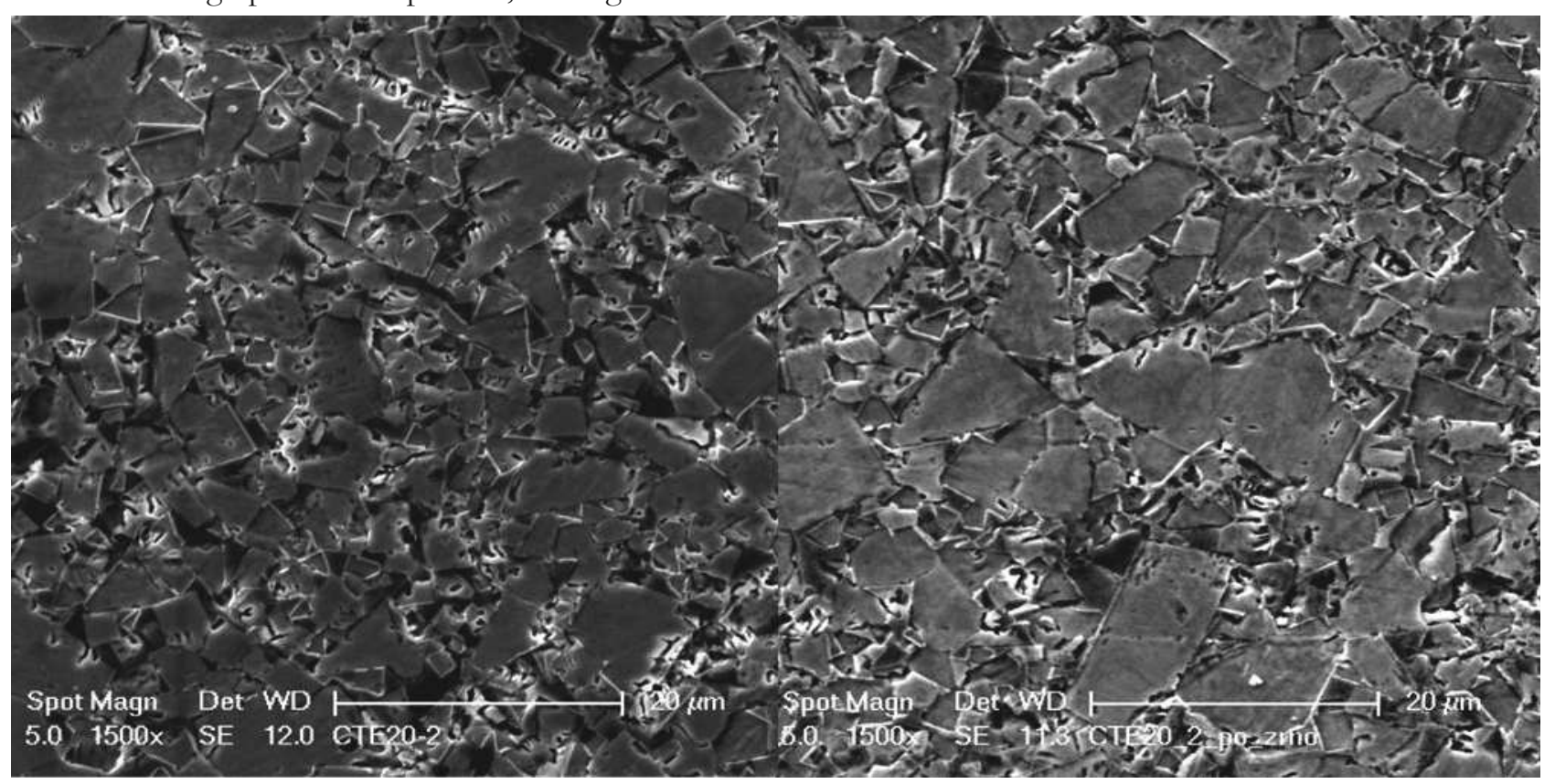

Fig. 3 An Eexample of CTE20 Specimens (10\% Co)-left: Prior to DCT-Estimated Grain Size $8 \mu m$, right: After DCT Estimated Grain Size $10 \mu \mathrm{m}$

Tab. 2 Average of equivalent diameter

\begin{tabular}{|c|c|c|}
\hline Specimen & $\begin{array}{l}\text { Average of equivalent diameter } \\
{[\mu \mathrm{m}]}\end{array}$ & Standard deviation $[\mu \mathrm{m}]$ \\
\hline CTE20 $(10 \%$ Co $)$ before DCT & 0.65 & 1.30 \\
\hline CTE20 $(10 \%$ Co $)$ after DCT & 2.04 & 1.64 \\
\hline CTE30 (15\%Co) before DCT & 1.07 & 1.65 \\
\hline CTE30 $(15 \%$ Co $)$ after DCT & 1.67 & 1.70 \\
\hline
\end{tabular}




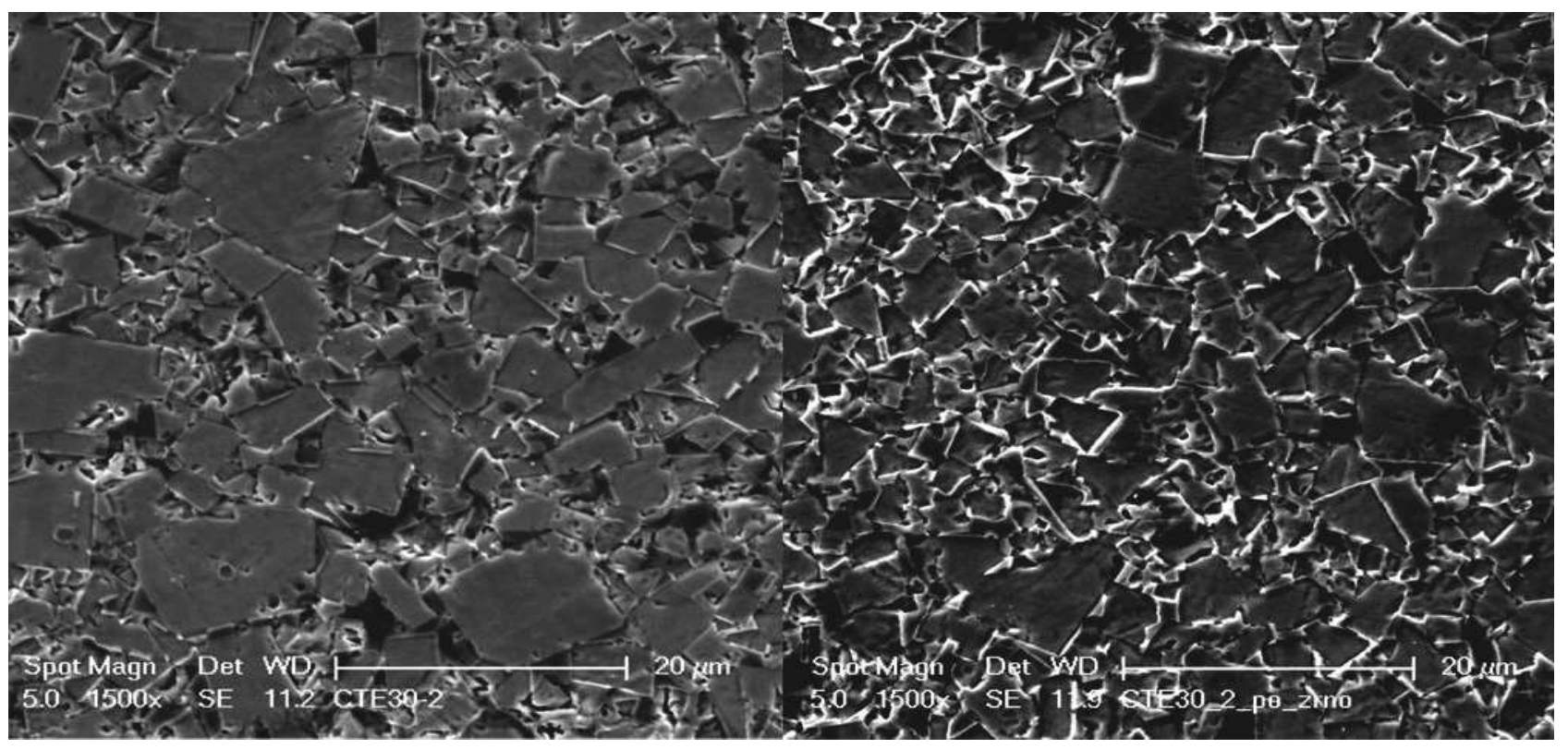

Fig. 4 An Eexample of CTE30 Specimens (15\% Co)-left: Prior to DCT-Estimated Grain Size $9 \mu m$, right: After DCT Estimated Grain Size $8 \mu \mathrm{m}$

The last one for measuring the grain size the image analysis software NIS - Elements AR v. 4.40 was used. The same images as for the previous method were used. The average area analysed in all specimens was $10000 \mu \mathrm{m}^{2}$. Fig. 6 shows an example of micrographs of CTE20, before and after thresholding.

Figure 7 shows a histogram of equivalent diameters of carbide grains in CTE20 (before and after DCT) specimens. Figure 8 shows a histogram of equivalent diameters of carbide grains in CTE30 (before and after DCT) specimens. The equivalent diameter of a 2-D outline is the diameter of the circle that contains the same area as the shape in question [16]. The results of the carbide grains size measurements are shown in Table 2.

The results from Table 2 shows that the carbide grain size increased after cryogenic treatment. This method is very time-consuming, but more accurate than the first one.
The Grain Size Before and After DCT

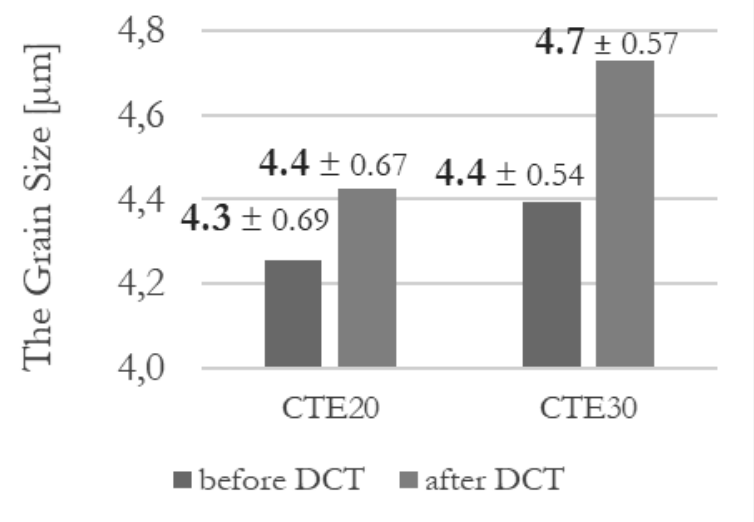

Fig. 5 The Grain Size Before and After DCT

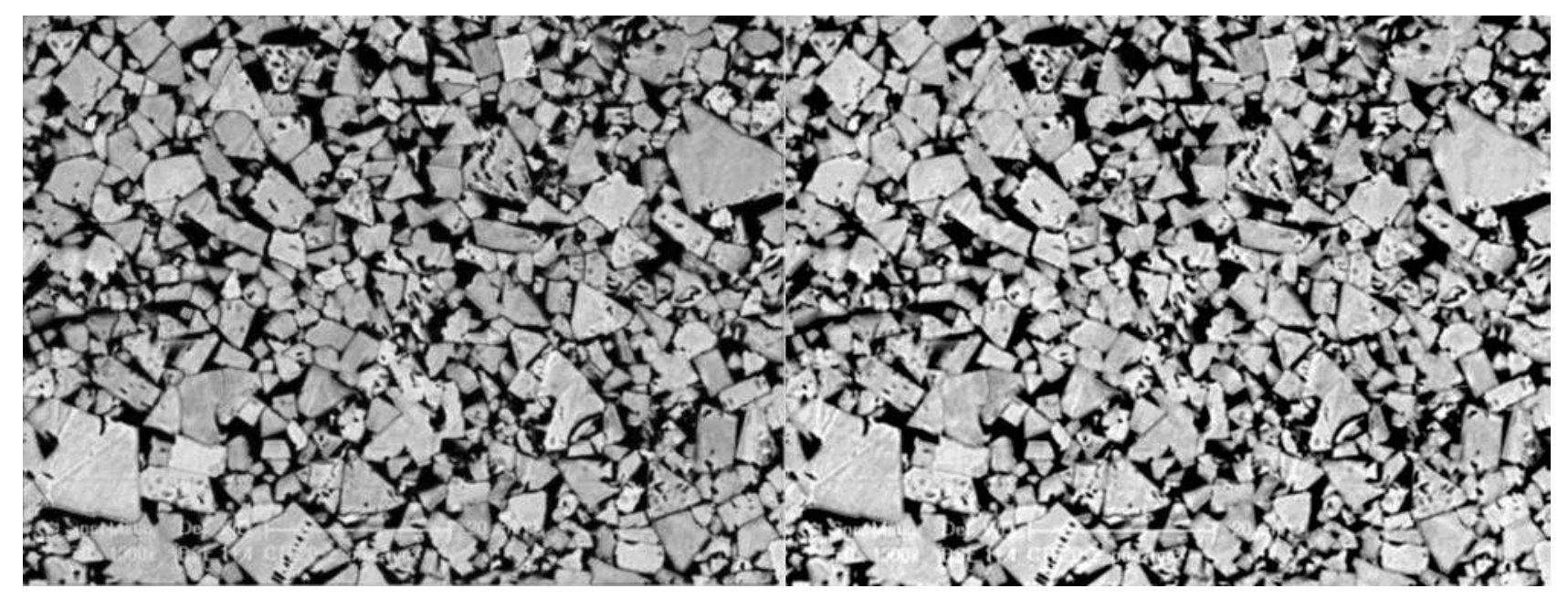

Fig. 6 An Example of Micrographs of CTE20, Before and After Thresholding 

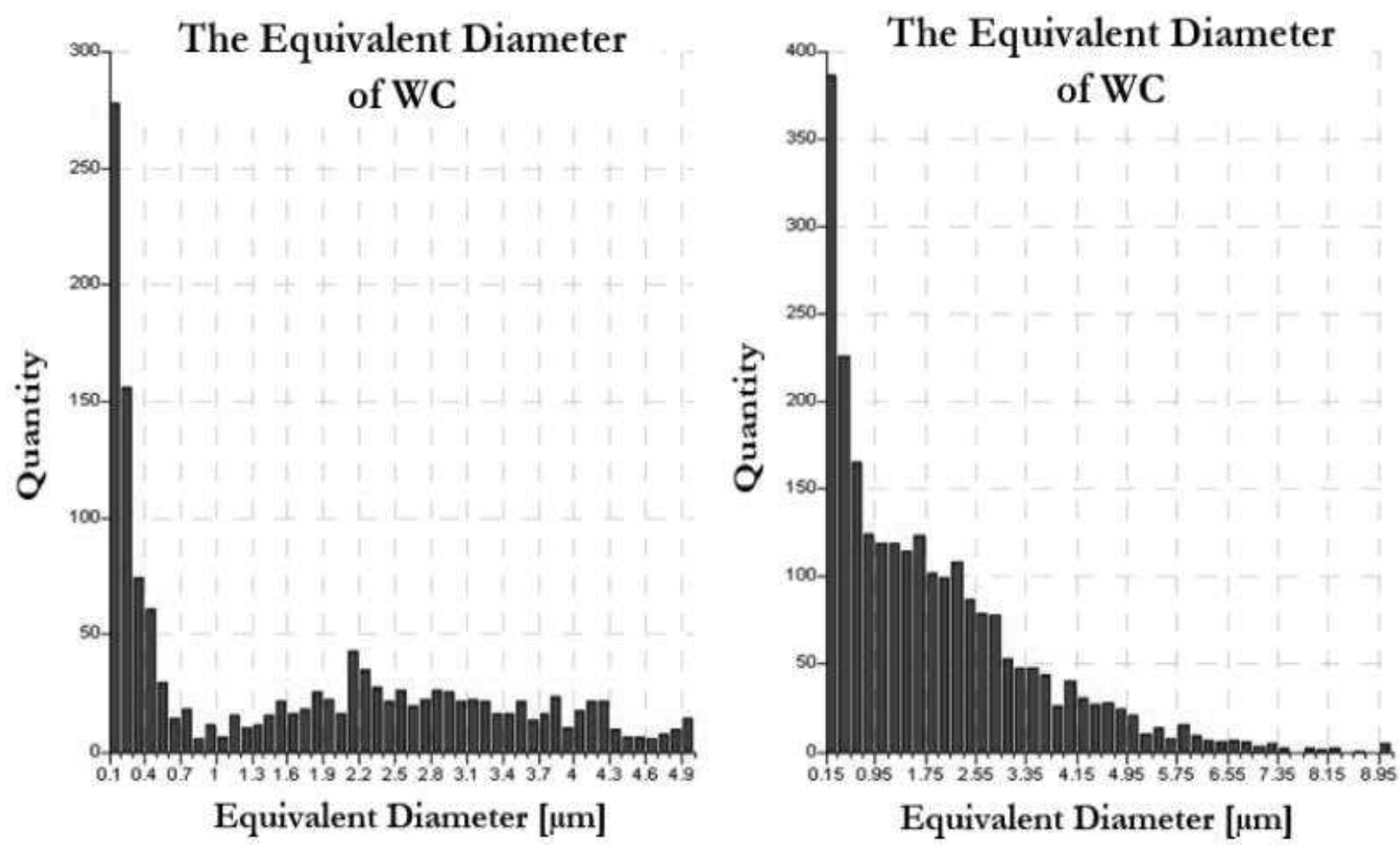

Fig. 7 Histograms of Equivalent Diameters of Carbide Grains in CTE20 (10\% Co) Specimens. Left - Before DCT, The Average of The Equivalent Diameter was $0.65 \pm 1.30 \mu \mathrm{m}$, right - After DCT, The Average of The Equivalent Diameter was $2.04 \pm 1.64 \mu \mathrm{m}$

The Equivalent Diameter

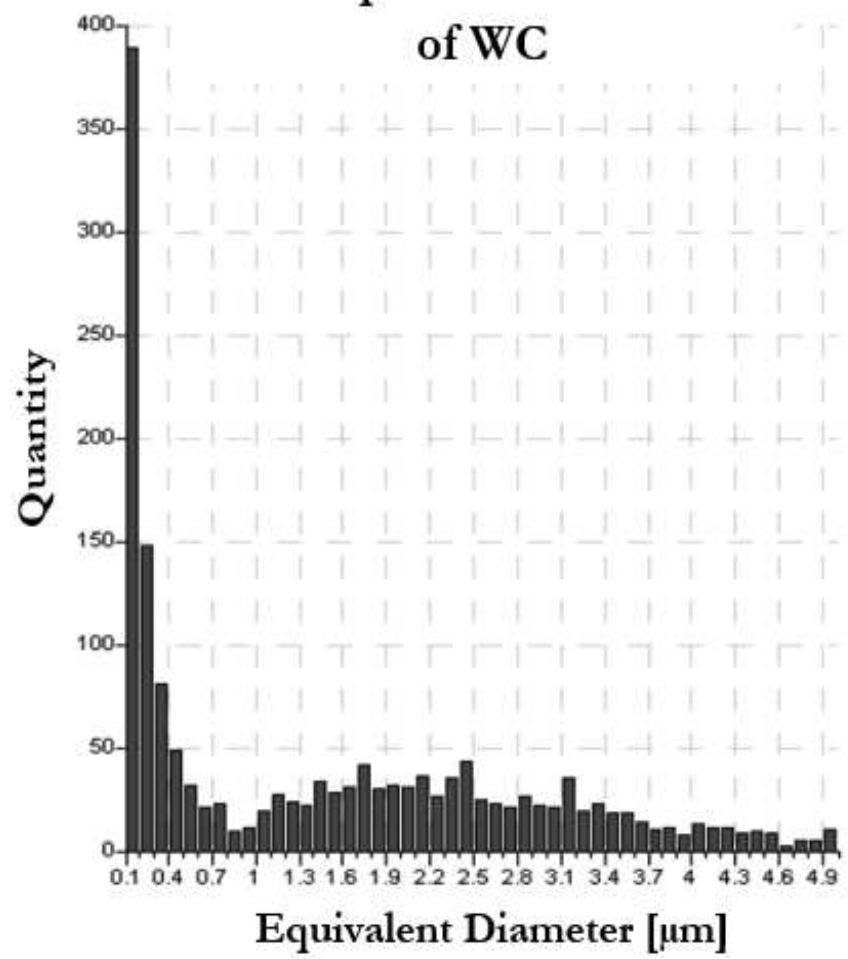

The Equivalent Diameter

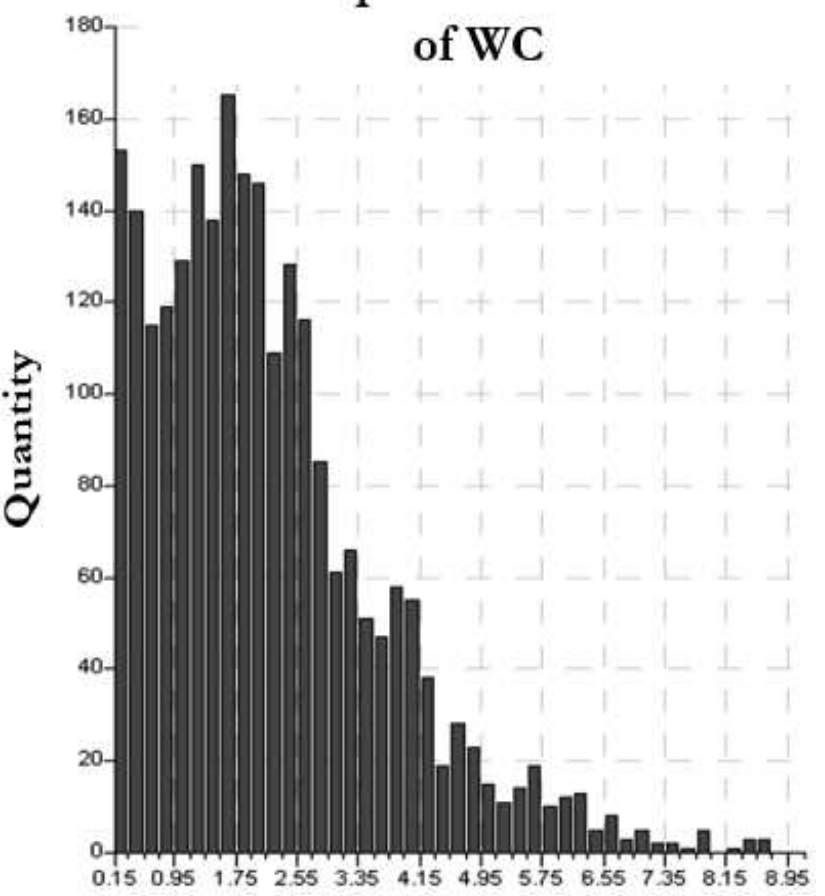

Equivalent Diameter $[\mu \mathrm{m}]$

Fig. 8 Histograms of Equivalent Diameters of Carbide Grains in CTE30 (15\% Co) Specimens. Left - Before DCT, The Average of The Equivalent Diameter was $1.07 \pm 1.65 \mu \mathrm{m}$, right - After DCT, The Average of The Equivalent Diameter was $1.67 \pm 1.70 \mu \mathrm{m}$ 

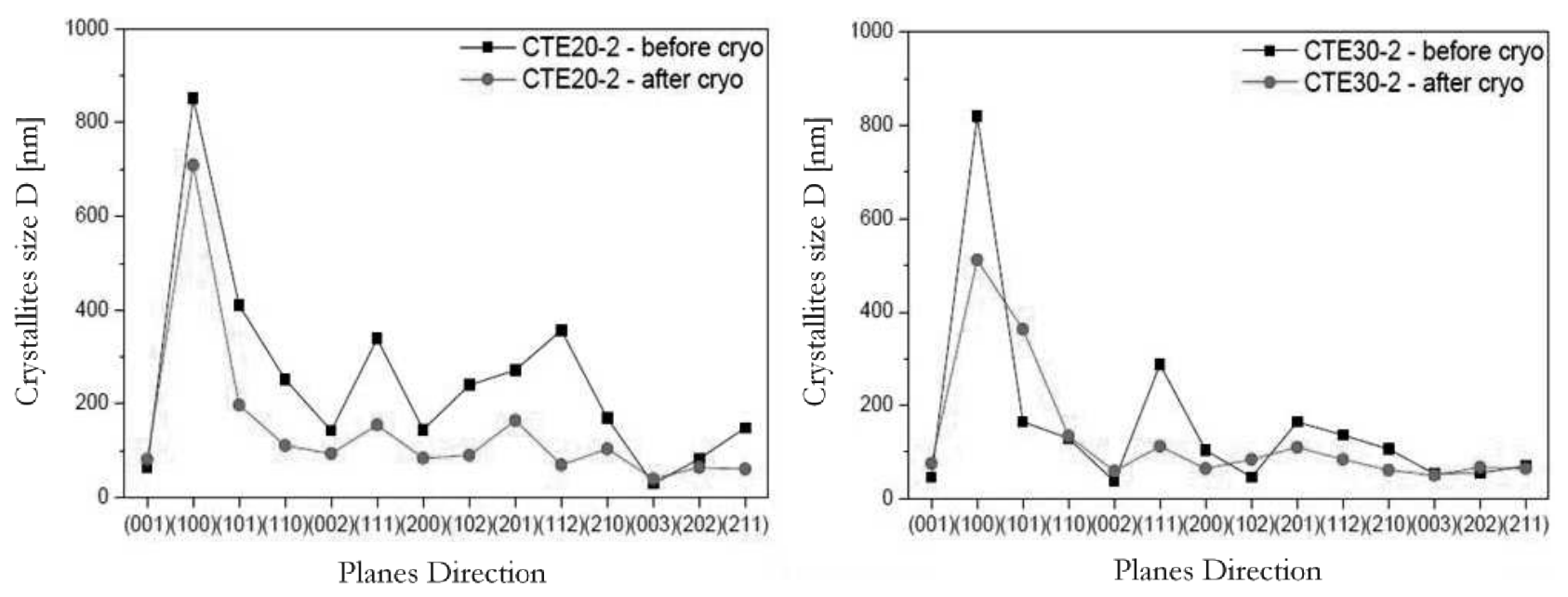

Fig. 9 The Crystallites Size of WC

In conclusion the size of the WC crystallites by $\mathrm{XRD}$ was measured. In both samples, the size of the crystallites decreased after cryogenic treatment, see Fig. 9.

The results above show that the evaluation of grain size according to ASTM 390 is very inaccurate and is only suitable for quick comparison. Both other methods are suitable for more accurate grain size measurements. The results of both methods show that there was a slight increase in carbide grain after cryogenic treatment. The result is in accordance with eg [8].

Finally, it is necessary to explain why a lower crystallite size was measured after cryogenic treatment. First, it is important to realize the differences between grain and crystallite. In the case of the grain size, we can say that the area of the grain is bounded interfacial interface. The regular structure is lost at this place. These are therefore units that are clearly distinguishable precisely by the boundary of these places, ie by the grain boundary.

Unlike this term, ie the grain boundary, a crystallite size is the area with coherent diffractive units. The area could be described as domain blocks. Crystallographic planes are coherently tilted to the incident Xray beams in this areas. The crystallographic planes are parallel to the surface, Braggs law is fulfilled and the constructive interferential is occur. The areas may be larger or smaller than the grain size and they do not have to be strictly bounded by a grain boundary. It depends on the orientation. In the case of polycrystalline material grains contain a large amount of the different size of the coherent diffractive units. The counted size is the average size of these units.

In the present work, due to cryogenic processing, the size of recrystallized grains increased while the size of coherently diffractive areas decreased. From the above, it can be concluded that the size of the crys- tallites decreased due to reduced coherence of the diffracting planes.

\section{Conclusion}

The paper addressed the effect of cryogenic processing on the size of grain and crystallites of WC carbide in sintered WC-Co carbide. The results show the following:

- The linear intersection method or image analysis using suitable software is most suitable for evaluating the WC grain size.

- After deep cryogenic treatment, there was a slight increase in carbide grain.

- The grain size of WC was increasing after deep cryogenic treatment.

- The crystallite size of WC was decreasing after deep cryogenic treatment.

\section{Acknowledgement}

This article was made possible by the funding for the SGS-2018-051 project "Application of new treatment and test procedures to surfaces and bulk materials for improved usability of assemblies and work tools in industry".

\section{References}

[1] GARCIA, Jose, et al. Cemented carbide microstructures: a review. International Journal of Refractory Metals and Hard Materials, 2019, 80: 4068.

[2] HUMÁR, A. (2006). Materiály pro rezzné nástroje (Interaktivní multimediální text pro všechny studijní programy FSI). Vysoké učení technické 
v Brně, Fakulta strojního inženýrství, Ústav strojírenské technologie, 2006.

[3] VINOD K. Sarin, Edited By LUIS LLANES, DANIELE MARI. (2014). Comprehensive hard materials, Volume 1, Hardmetals. Elsevier. ISBN 9780080965284.

[4] CHETAN, et al. (2017). Performance evaluation of deep cryogenic processed carbide inserts during dry turning of Nimonic 90 aerospace grade alloy. Tribology international, 2017, 115: 397-408.

[5] DHANDE, S. T., et al. (2018). Influence of soaking periods in cryogenic treatment of tungsten carbide. Procedia Manufacturing, 2018, 20: 318-328.

[6] XIE, YUAN-FENG, et al. (2019). Microstructure and properties of coarse-grained WC-10Co cemented carbides with different carbon contents during heat treatments. Rare Metals, 2019, 1-7.

[7] ÖZBEK, NURSEL ALTAN, et al. (2016). Effect of cutting conditions on wear performance of cryogenically treated tungsten carbide inserts in dry turning of stainless steel. Tribology International, 2016, 94: 223-233.

[8] GILL, Simranpreet Singh, et al. (2012). Metallurgical and mechanical characteristics of cryogenically treated tungsten carbide (WCCo). The International Journal of Advanced Manufacturing Technology, 2012, 58.1-4: 119-131.

[9] KIM S, HAN SH, PARK JK, KIM HE (2004). Variation of WC grain shape with carbon content in the WC-Co alloys during liquidphase sintering. Scr Mater 48:635

[10] CHRISTENSEN, M. (2004). Strength and stability of interfaces in cemented carbides, Thesis
No. 2133 (ISBN 91-7291-451-3). Chalmers University of Technology, Gothemburg

[11] NIRMAL S. KALSI, RAKESH SEHGAL \& VISHAL S. SHARMA (2010). Cryogenic Treatment of Tool Materials: A Review, Materials and Manufacturing Processes, 25:10, 1077-1100,

[12] Wear parts - a complete catalogue [online]. Ceratizit S.A., 2015 [cit. 2020-01-30]. Available at: https:// www.ceratizit.com/ uploads/tx_extproduct//files/GD_KT_PRO-0272915_SCS_ABS_V1.pdf

[13] About grinding and polishing. Struers.com [online]. [Accessed 2020-08-27]. Available at: https:// wwm.struers.com/en/Knowledge/Grindingand-polisbing\#

[14] ASTM B657-18, Standard Guide for Metallographic Identification of Microstructure in Cemented Carbides, ASTM International, West Conshohocken, PA, 2018, www.astm.org

[15] ASTM B390-92(2006), Standard Practice for Evaluating Apparent Grain Size and Distribution of Cemented Tungsten Carbides (Withdrawn 2010), ASTM International, West Conshohocken, PA, 2006, www.astm.org

[16] Manual NIS-Elements AR. Laboratory Imaging, spol. s.r.o., Praha, 2015.

[17] PRŮCHA, V., et al. (2019). Effect of Cryogenic Treatment on Properties of Cemented Carbides. Manufacturing Technology, 2019, roč. 19, č. 1, s. 129-134. ISSN: 1213-2489.

[18] PRŮCHA, V., et al. (2019). Analysis of Fractured Weldment of Hadfield Steel. Manufacturing Technology, 2019, roč. 19, č. 2, s. 308-313. ISSN: 1213-2489 